DOI: $10.18276 /$ pz.2015.2-11

\title{
Henryk Kocój, Dyplomaci sascy wobec powstania kościusz- kowskiego, Kraków 2013, ss. 445
}

Profesor Henryk Kocój, „najwybitniejszy współczesny polski znawca problematyki międzynarodowego układu sytuacji Rzeczypospolitej w okresie Sejmu Wielkiego oraz drugiego i trzeciego jej rozbioru", niestrudzony badacz epoki reform 17881792, a także zrywów wolnościowych: Insurekcji Kościuszkowskiej i Powstania Listopadowego, wydał kolejną książkę,

${ }^{1}$ M. Serwański, Dorobek naukowy profesora Bronisława Dembińskiego, w: Bronisław Dembiński (1858-1939). Wybitny historyk, polityk i działacz społeczny, pod red. W. Jastrzębskiego, Wyd. Adam Marszałek, Toruń 2004, s. 82. tym razem poświęconą stanowisku dyplomatów saskich wobec wydarzeń polskich 1794 roku. Zajmując się zmierzchem Rzeczypospolitej, jest on kontynuatorem dzieła innego wybitnego historyka - Bronisława Dembińskiego, wydawcy monumentalnej pracy Źródła do dziejów drugiego i trzeciego rozbioru Polski.

Tym razem H. Kocój, penetrując zasoby źródłowe Sachsisches Hauptstaatsarchiv Dresden, zwrócił uwagę na francuskojęzyczną korespondencję ówczesnego posła saskiego w Berlinie Friedricha Augusta Zinzendorfa, relacje posła saskiego 
w Wiedniu Johanna Hilmara Schoenfelda, instrukcje ministra spraw zagranicznych Johanna Adolfa Lossa dla Hansa Moritza Bruhla, posła saskiego w Londynie, oraz korespondencję z Johannem Jakobem Patzem, posłem saskim w Warszawie. Niestety, nie udało się autorowi dotrzeć do relacji posła saskiego z Petersburga - Gustava Georga Voelckersahma. Jego depesze zaginęły, gdy po 1945 r. znalazły się w ZSRR, skąd już nie wróciły do Drezna. Prezentowany wybór not i depesz jest poprzedzony obszernym i wartościowym wstępem, w którym autor omawia w skrócie dotychczasową literaturę przedmiotu oraz przybliża treść korespondencji.

Profesor H. Kocój, publikując noty saskich dyplomatów w niniejszym wydawnictwie, uwzględnił także część z ponad 100 załączników do depesz J.J. Patza, m.in. list Stanisława Augusta pisany do Katarzyny II 21 XI 1794 r., w którym król uskarżał się imperatorowej na złą sytuację ekonomiczną Rzeczypospolitej, przyrównując ją do pustyni. Znamienna jest też odpowiedź carowej, w której stwierdzała, iż Polska jest sama sobie winna, bo Polacy niepotrzebnie wywołali powstanie. $\mathrm{W}$ tym samym liście nakazywała polskiemu monarsze wyjazd ze stolicy do Grodna.

Z kolei manifest Mikołaja Repnina z 17 XII 1794 r., w którym nakazywał on mieszkańcom Litwy bezwzględne posłuszeństwo wobec dyrektyw z Petersburga i odcięcie się od polskich „,buntowników”, pokazywał nowe relacje Rosji z tą prowincją Rzeczypospolitej. Odtąd jej obywatele mieli się modlić za Katarzynę II, która „wyzwoliła ich z obcego ucisku”.
H. Kocój ocenia relacje J.J. Patza jako bardzo wartościowe źródła do opisu przebiegu insurekcji, zwłaszcza w Warszawie. Wpływ na to miała jego dobra znajomość polskich realiów. Dyplomata ten od 1780 r. pełnił funkcję sekretarza poselstwa saskiego w Warszawie, a od 1792 r. kierował jego pracami. Do jego informatorów należeli m.in. biskup kujawski Józef Rybiński i marszałek Fryderyk Moszyński, szef policji w czasach sejmu grodzieńskiego, podejrzany o powiązania $\mathrm{z}$ ambasadą rosyjską.

J.J. Patz nie był przyjazny sprawom polskim, czego wyraz stanowiła pełna jego aprobata polityki mocarstw rozbiorowych wobec Rzeczypospolitej. Równocześnie (na co H. Kocój zwraca uwagę) wszystko, co w jakikolwiek sposób łączyło się z jakobinizmem i rewolucją francuską, budziło w nim głęboką odrazę. Zdaniem J.J. Patza, poważną rolę w przygotowaniu powstania miał odegrać były poseł francuski z okresu Sejmu Wielkiego Maria Louis Descorches. Powstaniu kościuszkowskiemu, mimo zwycięskiej batalii racławickiej, wróżył szybki upadek i był do niego nastawiony nieprzychylnie. Jako głównych przywódców insurekcji wskazywał Ignacego Potockiego i Hugona Kołłątaja, którego uważał za intryganta podburzającego lud stolicy do wystąpień rewolucyjnych w maju i czerwcu 1794 r. Ściśle trzymając się instrukcji napływających od ministra Johanna Adolfa Lossa z Drezna, unikał składania jakichkolwiek urzędowych oświadczeń i dlatego nawet wówczas, gdy spotykał się z ministrem spraw zagranicz- 
nych Ignacym Potockim, podkreślał nieoficjalny charakter rozmów.

W depeszy z 7 V 1794 r. donosił o ujawnieniu opinii publicznej zawartości archiwów rosyjskiej ambasady w Warszawie. „Krążą pogłoski - pisał J.J. Patz - że po zbadaniu archiwów rosyjskich wiele osób zarówno ze sfer wyższych, jak i niższych zostanie skompromitowanych. Nazwisko króla polskiego i jego rodziny powtarza się w tych pismach wielokrotnie. Toteż on i jego krewni są niezwykle przygnębieni z tego powodu. Prymas nie nocuje już w swoim pałacu, lecz zawsze przebywa w zamku z królem. Powiadają, że obawia się aresztowania"2.

J.J. Patz 10 V 1794 r. z wyrazami niechęci i oburzenia relacjonował przebieg egzekucji wykonanych na przywódcach targowicy: „Od momentu dotarcia tu wiadomości o powieszeniu w Wilnie hetmana [wielkiego litewskiego Szymona Marcina - Z.J.] Kossakowskiego za zbrodnię zdrady stanu pospólstwo domagało się natarczywie stracenia czterech więźniów. Aby uspokoić wzburzone umysły, przewieziono ich w nocy 7 bm. z Pałacu Rzeczypospolitej do piwnic prochowni, gdzie mieści się więzienie dla przestępców kryminalnych. Jakkolwiek mieszkańcy stolicy mniemać mogli, że zbrodnie pozostaną bezkarne, to jednak wczoraj o brzasku wzniesiono trzy szubienice przed ratuszem i czwartą

2 H. Kocój, Dyplomaci sascy wobec powstania kościuszkowskiego, Kraków 2013, s. 26, 57; Saechsiches Hauptstaatsarchiv Dresden, 10026 Geheimes Kabinett, Loc. 3577/3, No 36. Patz a Loss, Varsovie, le 7 mai 1794, ps a Dresde, le 17 mai 1794, p. 302-305. na Krakowskim Przedmieściu, naprzeciw kościoła Bernardynów, nad nimi zaś widniał napis: »Kara dla zdrajców Ojczyzny«. Jednocześnie zmuszono sędziów do wydania wyroku śmierci na owych czterech więźniów z natychmiastowym jego wykonaniem, i faktycznie stało się to wczoraj. Hetman wielki [koronny Piotr - Z.J.] Ożarowski, hetman polny [litewski Józef - Z.J.] Zabiełło i marszałek Rady Nieustającej [Józef - Z.J.] Ankwicz ${ }^{3}$ zostali powieszeni około południa na trzech szubienicach przed ratuszem Starego Miasta. Mimo próśb i nalegań nuncjusza apostolskiego, zwracającego uwagę na kapłański stan biskupa [inflancko-piltyńskiego Józefa Kazimierza - Z.J.] Kossakowskiego, nieszczęśliwiec ten również został powieszony na czwartej szubienicy, wzniesionej przed kościołem Bernardynów. Przedtem pozbawiono go godności kapłańskich, jakkolwiek odbyło się to niezgodnie z rytuałem obowiązującym w kościele rzymskim. Wypadek ten wywrze niewątpliwie bardzo niekorzystne wrażenie w Stolicy Apostolskiej, a także na innych europej-

${ }^{3}$ J. Ankwicz został mianowany przez władze konfederacji targowickiej komisarzem Komisji Edukacji Narodowej Koronnej. Był członkiem konfederacji grodzieńskiej 1793 r. Na sejmie grodzieńskim w 1793 r. został mianowany przez króla Stanisława Augusta Poniatowskiego członkiem deputacji do rozmów z posłem rosyjskim Jakowem Jefimowiczem Sieversem. Na posiedzeniu 23 września, wobec milczącego oporu izby przeciw wnioskowi o zgodę na nowy zabór pruski, oświadczył, że „milczenie oznacza zgodę". Pod koniec obrad sejmu grodzieńskiego został marszałkiem Rady Nieustającej przy poparciu rosyjskiego ambasadora. 
skich dworach"4. W tak drastycznych metodach działania J.J. Patz dopatrywał się podobieństw między Polską a rewolucyjną Francją.

Opinię tę utrwaliły w saskim dyplomacie wydarzenia z 28 VI 1794 r., gdy lud Warszawy przystąpił do wieszania zdrajców. Pisał on: „W nocy z piątku na sobotę postawiono 6 szubienic na Rynku Starego Miasta; na jednej zawisł [sekretarz do spraw tureckich w Departamencie Interesów Cudzoziemskich Rady Nieustającej Karol - Z.J.] Boscamp-Lasopolski, na drugiej szambelan [Stefan - Z.J.] Grabowski i instygator [koronny, intendent policji, szpieg i jurgieltnik rosyjski Mateusz - Z.J.] Roguski, na trzeciej instygator [sądów kryminalnych Józef - Z.J.] Majewski i [pracownik policji, szpieg i jurgieltnik rosyjski Marceli - Z.J.] Piętka. Na czwartej szubienicy, wystawionej na Krakowskim Przedmieściu, powieszony został adwokat [Michał Franciszek - Z.J.] Wulfers, a na piątej, wzniesionej przed pałacem hrabiego Branickiego, książę [Antoni Stanisław Światopełk - Z.J.] Czetwertyński, zaś na szóstej, przed pałacem Bruhla, biskup [wileński Ignacy Jakub - Z.J.] Massalski. Wszyscy zostali powieszeni bez żadnego procesu sądowego i nie przez kata, ale rękami pospólstwa, w sposób jak najbardziej barbarzyński"5.

Równie ostro oceniał aresztowanie Josefa Auberta, radcy ambasady rosyjskiej, któremu odmawiano statusu członka korpusu dyplomatycznego. „Pospólstwo

\footnotetext{
${ }^{4}$ H. Kocój, Dyplomaci sascy..., s. 26.

${ }^{5}$ Ibidem, s. 28.
}

- pisał J.J. Patz - wbrew wszelkiemu rozsądkowi, domaga się wszczęcia przeciwko niemu procesu kryminalnego, gdyż w archiwach generała Osipa Andriejewicza Igelstroema znaleziono listę proskrypcyjną przeciwników Rosji pisaną jego ręką"6.

Reprezentant Wettynów donosił także o bezwzględności i mściwości wojsk rosyjskich dopuszczających się zbrodniczych okrucieństw i gwałtów na bezbronnej ludności wsi i miasteczek. W depeszy z 30 IV 1794 r. pisał: „Rosyjscy uciekinierzy dopuszczają się prawie wszędzie niezwykłych okrucieństw. Zabijają mieszkańców wsi i rabują ich zabudowania"7. Ponadto w tejże relacji zwracał uwagę na ogromny wysiłek władz powstańczych, by zapewnić Warszawie należytą obronę w razie ataku Rosjan ${ }^{8}$

Momentem przełomowym była klęska Tadeusza Kościuszki poniesiona pod Maciejowicami, o której 15 X 1794 r. donosił: ,że Kościuszko [...] ranny dostał się do niewoli niemal $\mathrm{z}$ całym sztabem i generałami: [Karolem - Z.J.] Sierakowskim, [Michałem Ignacym - Z.J.] Kamieńskim i innymi. Wszystkie działa w liczbie 25 do 30 sztuk stracono. Żołnierze polegli albo dostali się do niewoli, lub rozproszeni w małych grupkach ciągną ku Warszawie, wszyscy nieludzko zmęczeni i bez broni. Rozpacz maluje się na ich twarzach" ${ }^{\text {". W tej }}$ sytuacji nie widział już wielkich szans

\footnotetext{
${ }^{6}$ Ibidem, s. 27.

${ }^{7}$ Ibidem, s. 25.

${ }^{8}$ Ibidem, s. 26

${ }^{9}$ Ibidem, s. 30.
} 
dla powstania. W jego mniemaniu Polacy „rozpoczynając wojnę, nie dysponowali dostateczną ilością broni palnej. Dlatego też uzbroili chłopów w kosy i piki. Dziś - relacjonował J.J. Patz - sytuacja uległa dalszemu pogorszeniu, skoro w obu operacjach Karola Sierakowskiego i Tadeusza Kościuszki utracono 8000-10000 sztuk broni palnej"10. Ponadto zwracał on uwage na takie czynniki, jak zawężenie terytorium będącego pod kontrolą powstańców, brak możliwości poboru rekruta i czasu na jego wyszkolenie, gdy wróg stał u bram stolicy.

W liście z 24 XII 1794 r., już po zajęciu przez Rosjan Warszawy, interesujące jest omówienie depeszy Katarzyny II do Stanisława Augusta. Imperatorowa radziła królowi „opuścić jak najszybciej to grzeszne i przestępcze miasto" i udać się do Grodna, ,gdzie znajdzie wszystkie wygody, jakich tylko zapragnie, zgodnie z wydanymi już przez nią rozkazami w tej sprawie"11. Ten sam kurier przywiózł także rozkazy dla feldmarszałka A. Suworowa, dotyczące uwięzienia i uprowadzenia do Rosji głównych przywódców powstania, na czele z marszałkiem litewskim Ignacym Potockim, któremu wcześniej dowódca rosyjski zaręczył bezpieczeństwo.

Zwycięzcy myśleli już tylko o podziale łupów. A. Suworowowi carowa podarowała brylantową szlifę do kapelusza i 3 zdobyczne armaty. Na wieść o zdobyciu Warszawy po odczytaniu raportu A. Suworowa: „Hurra! Warszawa nasza!” Kata-

\footnotetext{
10 Ibidem.

${ }^{11}$ Ibidem, s. 31.
}

rzyna II odpisała: „Hurra feldmarszałku!”. Wraz z nominacją feldmarszałek otrzymał buławę wysadzaną diamentami i 7000 dusz chłopskich. Franciszek II przesłał mu swój portret, a Fryderyk Wilhelm II gwiazdę Orderu Orła Czarnego. Oficerów nagrodzono złotymi krzyżami na wstędze św. Jerzego z napisem „Praga wzięta 24 X 1794 roku”, każdy podoficer i żołnierz dostał medal i jednego rubla. Były jeszcze inne profity z tej wyprawy, o których mówiła pieśń żołnierzy Aleksandra Wasilijewicza Suworowa pt. Idiom grabit' Polszu.

Mimo nieprzyjaznego stosunku do powstania J.J. Patz zdobył się na obiektywną charakterystykę jego przywódcy, Tadeusza Kościuszki. Już po bitwie maciejowickiej napisał: „Mówiąc szczerze, był on pośród wszystkich rewolucjonistów człowiekiem najbardziej uczciwym, prawym i moralnym. Swą wrodzoną uprzejmością, skromnością i oszczędnością, którą do końca zachował, zasłużył sobie na entuzjazm, którym darzyło go społeczeństwo"12.

Według H. Kocója pewną wartość posiadają również inne drobiazgowe i z pozoru drugorzędne spostrzeżenia dotyczące spraw zagranicznych, możliwości wybuchu wojny rosyjsko-tureckiej, a także niedoborów w uzbrojeniu armii powstańczej. Pełne dramaturgii były doniesienia dotyczące schyłku powstania i przygotowań Stanisława Augusta do opuszczenia Warszawy. W szczególności zaś relacja opisująca spotkanie Poniatowskiego z Mikołajem Wasilijewiczem Repninem w Grodnie,

12 Ibidem, s. 17. 
który ostentacyjnie oświadczył królowi, iż „Nie ma już Polski” i zakazywał jakiejkolwiek korespondencji $\mathrm{z}$ byłymi przywódcami insurekcji. Jest to dalszy ciąg upokorzeń, jakie musiał znosić Stanisław August ze strony swej mocodawczyni od czasów sejmu grodzieńskiego 1793 r., na którym zapadła uchwała o przywróceniu Orderu Virtuti Militari. J.J. Patz w depeszy z 1 I 1794 r. donosił o głębokim niezadowoleniu, jakie z tej przyczyny Katarzyna II wyraziła wobec Polski. Chcąc załagodzić oburzenie carycy, król po konsultacjach z przedstawicielami Rosji w Warszawie - Jakowem Jefimowiczem Sieversem i Osipem Andriejewiczem Igelstroemem - zwołał posiedzenie Rady Nieustającej, w czasie którego postanowiono zakazać noszenia tych orderów zarówno w kraju, jak i za granicą oraz wysłać specjalną deputację z pokornymi przeprosinami do $\mathrm{Pe}$ tersburga ${ }^{13}$, „W raporcie z 29 I 1794 r. poseł saski donosił o tym, że z Rosji nadeszła pozytywna odpowiedź o usatysfakcjonowaniu cesarzowej w związku z przesłanymi do Petersburga pokornymi prośbami Rady Nieustającej o wybaczenie"14. Jego uwagi nie uszło, iż podporządkowanie Rosji, uległość i służalczość władz polskich ze Stanisławem Augustem na czele wywoływała silne emocje wśród Polaków. Według J.J. Patza powodem szczególnego wzburzenia był uniwersał o kasacji polskich odznaczeń wojskowych. Odbierano to jako wielkie poniżenie. Zachowanie takie nie było

${ }^{13}$ Ibidem, s. 18, 53.

${ }^{14}$ Ibidem, s. 18. zgodne z tym, czego obywatele powinni oczekiwać od suwerennego państwa ${ }^{15}$.

Upadek Polski był jednak bliski. ,Nazajutrz po wyjeździe króla, pan Diwow, radca poselstwa rosyjskiego, udał się do ministrów cudzoziemskich, by oznajmić im zgodnie z poleceniem feldmarszałka A. Suworowa, że z chwilą wyjazdu króla do Grodna ustaje działalność wszystkich misji zagranicznych w Warszawie"l6.

Podobnie jak J.J. Patz oceniał powstanie i międzynarodowe uwarunkowania saski minister spraw zagranicznych Johann Adolf Loss. Jednak zdaniem H. Kocója ważniejsze od korespondencji Patza z Lossem są doniesienia posła saskiego w Berlinie - Friedricha Zinzendorfa. „Ten dyplomata saski - według badacza - tkwił głęboko w centrum wielkiej polityki międzynarodowej i powstanie polskie oceniał z uwzględnieniem dalekosiężnych interesów Prus i Rosji. Rezydując w doborowym towarzystwie dyplomatów pruskich, rosyjskich, austriackich i angielskich, potrafił sobie wyrobić własny pogląd na politykę wielkich mocarstw wobec polskiego zrywu niepodległościowego i z tej perspektywy omawiał szansę polskich powstańców w starciu z głównymi potęgami europejskimi""17.

Udostępnienie szerokiemu gronu czytelników tak ważnych i cennych materiałów źródłowych stanowi dużej rangi wydarzenie naukowe. Zbiór depesz i not jest bardzo obfity, liczy w sumie kilkaset

\footnotetext{
15 Ibidem.

16 Ibidem, s. 32.

17 Ibidem, s. 34.
} 
listów. Opublikowano je w układzie chronologicznym, dzieląc na części - stosownie do autorstwa. Precyzyjny ich wykaz na początku książki bardzo ułatwia korzystanie z tej obszernej pracy i pozwala na szybkie odnalezienie konkretnego listu. Każda z depesz została opatrzona sygnaturą archiwum, nazwiskiem nadawcy i adresata oraz miejscem i datą nadania. Aneks znajdujący się na końcu, prezentujący dla przykładu faksymile oryginalnych not i depesz, daje wyobrażenie, jaką pracę wykonał H. Kocój, aby odczytać i rozszyfrować treść dyplomatycznej korespondencji. Jedynym mankamentem dzieła jest brak indeksu osobowego oraz literówka w nazwisku Kamiński na s. 30. Autorowi zapewne chodziło o Michała Ignacego Kamieńskiego (1758-1815), który w roku 1792 walczył przeciwko interwencji rosyjskiej i odznaczył się pod Wiszniopolem, uzyskał awans w 1793 r. na pułkownika i został kawalerem Krzyża Orderu Virtuti Militari. Z kolei 10 IV 1794 r. po wyróżnieniu się w bitwie pod Szczekocinami awansował na generała majora, a pod Maciejowicami dostał się do niewoli rosyjskiej.

Dzięki ogromnemu wysiłkowi autora i jego erudycji otrzymaliśmy pracę ważną, stanowiącą wartościowe i wieloaspektowe uzupełnienie obrazu Insurekcji Kościuszkowskiej. Opublikowana w oryginalnej wersji językowej korespondencja saskich dyplomatów jest pierwszorzędnym źródłem do głębszego poznania antypowstańczych działań wrogich Polsce dworów. Książka zasługuje na szczególną uwagę badaczy zajmujących się zgłębianiem meandrów dyplomacji w dobie oświecenia, a także historyków wojskowości.

ZDZISEAW JANECZEK 